\title{
OPTIMALISASI PERAN PERPUSTAKAAN SEBAGAI SARANA KOMUNIKASI ILMIAH: STUDI KASUS DI PERPUSTAKAAN UNIVERSITAS SEBELAS MARET SURAKARTA
}

\author{
Sri Anawati* \\ Perpustakaan Universitas Sebelas Maret Surakarta \\ *Korespondensi: srianawatisolo@gmail.com
}

Diajukan: 17-02-2019; Direview: 05-03-2019; Diterima: 16-05-2019; Direvisi: 25-10-2019

\begin{abstract}
The college library means of scientific communication must utilize information technology as a means of supporting information dissemination. The library as one of the media in the chain of scientific communication, serves as a center of information both in printed and electronic forms. The research method used is observation of the role of the UNS Library as a means of scientific communication. The role of the UNS Library as a means of scientific communication namely: (1) providing ejournal content, digital library, institutional repository, journals and other publications that is published by UNS; and (2) information literacy, like as user education, collaboration between librarians and lecturers; information retrieval services, and periodical training.
\end{abstract}

\begin{abstract}
ABSTRAK
Perpustakaan perguruan tinggi sebagai sarana komunikasi ilmiah harus memanfaatkan teknologi informasi sebagai sarana penunjang dalam penyebaran informasi. Perpustakaan sebagai salah satu media dalam mata rantai komunikasi ilmiah, berfungsi sebagai pusat informasi baik dalam bentuk cetak maupun elektronik. Metode penelitian yang digunakan yaitu pengamatan terhadap peran Perpustakaan UNS sebagai sarana komunikasi ilmiah. Peran Perpustakaan UNS sebagai sarana komunikasi ilmiah yaitu: (1) menyediakan konten ejournal, perpustakaan digital, repositori institusi, jurnal dan terbitan civitas UNS; dan (2) literasi informasi, melalui kegiatan pendidikan, kolaborasi pustakawan dengan dosen, layanan penelusuran informasi, dan pelatihan secara berkala.
\end{abstract}

Keywords: Scholarly communication; Information resources; Institutional repository; Academic library

\section{PENDAHULUAN}

Undang-Undang Nomor 43 Tahun 2007 Pasal 24 ayat 3 menjelaskan bahwa perpustakaan perguruan tinggi mengembangkan layanan perpustakaan berbasis teknologi informasi dan komunikasi. Dalam manajemen sarana komunikasi, perpustakaan perguruan tinggi harus memanfaatkan teknologi informasi sebagai sarana penunjang dalam penyebaran informasi dan membangun komunikasi ilmiah dengan penggunanya. Terkait hal tersebut, perpustakaan dituntut untuk menjadi pengelola informasi dengan memanfaatkan perkembangan teknologi informasi.

Teknologi informasi yang semakin berkembang memacu perpustakaan untuk menyediakan koleksi tidak hanya dalam bentuk tercetak tetapi juga dalam bentuk elektronik, seperti jurnal elektronik (ejournal) yang dimanfaatkan untuk menunjang bidang penelitian. Jurnal ilmiah memuat isi terkini (current). Jurnal ilmiah sebagai media kreasi/penemuan para dosen, peneliti dan praktisi dalam pengembangan profesinya yang dilakukan secara berkelanjutan, serta sebagai gagasan dan ide kreatif bagi sivitas perguruan tinggi yang diimplementasikan dalam berbagai model penelitian. 
Perpustakaan sebagai salah satu media dalam mata rantai komunikasi ilmiah. Fungsi perpustakaan sebagai pusat informasi yaitu mengumpulkan serta menyebarluaskan berbagai informasi baik informasi yang sifatnya umum maupun ilmiah. Peran perpustakaan sebagai pusat informasi serta ilmu pengetahuan berhubungan dengan perkembangan teknologi. Jurnal sebagai wahana komunikasi ilmiah dan sekaligus tolok ukur kemajuan ilmu pengetahuan dan teknologi di lingkungan perguruan tinggi. Meningkatnya tuntutan pengguna terhadap kebutuhan informasi yang beragam, membuat UPT Perpustakaan Universitas Sebelas Maret Surakarta (selanjutnya disebut Perpustakaan UNS) perlu menerapkan berbagai strategi untuk pengembangan layanan informasi yang sesuai dengan kebutuhan pengguna.

\section{TINJAUAN PUSTAKA}

\subsection{Perpustakaan Perguruan Tinggi}

Perpustakaan perguruan tinggi adalah perpustakaan yang terdapat pada perguruan tinggi, badan di bawahan, maupun lembaga yang berafiliasi dengan perguruan tinggi, dengan tujuan utama membantu perguruan tinggi mencapai tujuannya, yakni Tri Dharma Perguruan Tinggi (pendidikan, penelitian, dan pengabdian masyarakat) (Sulistyo-Basuki, 1993). Menurut Qalyubi (2003) perpustakaan perguruan tinggi adalah Unit Pelaksana Teknis (UPT) perguruan tinggi yang bersama-sama dengan unit lain melaksanakan Tri Dharma Perguruan Tinggi dengan cara memilih, menghimpun, mengolah, merawat, dan melayankan sumber informasi kepada lembaga induknya pada khususnya dan masyarakat akademis pada umumnya. Perpustakaan perguruan tinggi sering disebut perpustakaan penelitian karena memang fungsi utamanya untuk sarana meneliti, dan meneliti merupakan salah satu kegiatan utama di perguruan tinggi (Sutarno, 2006).

Berdasarkan Permendikbud RI No.82 Tahun 2014 tentang Organisasi dan Tata Kerja Universitas Sebelas Maret, tugas UPT Perpustakaan adalah memberikan layanan kepustakaan dan memiliki fungsi: (1) penyusunan rencana, program, dan anggaran UPT; (2) penyusunan rencana, kebutuhan, dan penyediaan pustaka; (3) pengolahan bahan pustaka; (4) pemberian layanan dan pendayagunaan bahan pustaka; (5) pemeliharaan bahan pustaka; dan (6) pelaksana urusan tata usaha UPT). Adapun visi UPT Perpustakaan, yaitu menjadi pusat sumber belajar, penelitian, pengabdian kepada masyarakat dan layanan informasi yang prima dan unggul di tingkat dunia pada tahun 2030.

\subsection{Komunikasi Ilmiah}

Prahastuti (2006) menjelaskan asal kata komunikasi ilmiah berdasarkan pendapat Corea. Dituliskan bahwa komunikasi berasal dari kata latin "communicare" yang artinya membuat jadi biasa, berbagai, mengimpor dan mentranmisikan. Dari kata tersebut muncul kata communication, communicate, dan communicator. Pada awalnya ilmuwan melakukan komunikasi melalui surat menyurat. Kemudian setelah ditemukannya mesin cetak mereka berkomunikasi secara formal melalui buku dan trestise. Namun, komunikasi memerlukan waktu yang lama karena proses pembuatan buku yang memerlukan waktu relatif lama, dan akhirnya mereka menggunakan majalah sebagai sarana komunikasi formal karena majalah dapat diterbitkan lebih cepat (Sulistyo-Basuki, 1994:4-5).

Sedangkan kata ilmiah (scholarly atau scientific) umumnya digunakan untuk kegiatan yang berhubungan dengan penelitian atau penyelidikan, khususnya di lingkungan akademik. Dalam Kamus Kepustakawan Indonesia (2009), komunikasi ilmiah adalah komunikasi yang 
berlangsung antar-ilmuwan, yakni memberitahuan, pengalihan, penerusan, maupun penyampaian informasi dalam bidang tertentu kepada ilmuan lain.

Komunikasi ilmiah merupakan bagian penting dari pekerjaan seorang peneliti (Lacy \& Bush, 1983). Komunikasi ilmiah merupakan sarana bagi peneliti untuk saling mengetahui perkembangan ilmu, perkembangan penelitian yang dilakukan oleh rekannya, menjadi sarana untuk memberikan masukan terhadap penelitian yang sedang dilakukan rekannya. Fungsi dari komunikasi ilmiah diantara peneliti adalah untuk mengetahui penelitian apa yang sedang mereka kerjakan, mengevaluasi, menyebarkan, dan memanfaatkan kapasitas sebagai seorang peneliti untuk mengembangkan pengetahuan ilmiah (Beni, 2002).

Prahastuti (2006) dalam Kirez mengatakan ada beberapa fungsi komunikasi ilmiah, diantaranya: (1) fungsi sertifikasi, berhubungan dengan pengesahan kualitas penelitian dan standar ilmiah di dalam program penelitian; (2) fungsi registrasi, berhubungan dengan penelitian tertentu dengan individu ilmuwan yang mengklaim prioritas untuk penelitianfungsi ini terkait erat dengan perlindungan kepemilikan, sistem penghargaan, dan pada jangkauan yang luas sehingga mempengaruhi dinamika sosial dalam sistem; (3) fungsi kesadaran, yang mengarah pada kebutuhan informasi; (4) fungsi pengarsipan, berhubungan dengan penyimpanan dan aksesibilitas informasi.

\section{METODE}

Penelitian ini menggunakan metode observasi untuk mendapatkan data. Tempat penelitian di Perpustakaan UNS. Sumber pengumpulan data melalui database database perpustakaan digital/ repositori lembaga, e-journal, database jurnal internasional yang dilanggan oleh Perpustakaan UNS, dan sumber literatur lain. Pembahasan difokuskan pada peran Perpustakaan UNS sebagai media komunikasi ilmiah, yakni memfasilitasi atau memberikan sarana komunikasi ilmiah bagi peneliti sehingga hasil penelitiannya bermanfaat bagi sivitas pegawai UNS dan masyarakat.

\section{HASIL DAN PEMBAHASAN}

\subsection{Penyediaan Konten Informasi}

1) E-Journal

E-journal dapat diakses melalui laman https://library.uns.ac.id/ atau langsung di databasenya. Sivitas akademika dapat melakukan akses dan download tanpa harus ke Perpustakaan UNS. Hal ini memberikan kemudahan agar informasi yang terkandung didalamnya dapat dengan mudah, cepat, dan tepat diakses oleh pengguna yang sedang menyelesaikan karya tulis ilmiahnya. Data layanan per-Januari 2019 diketahui ada 1014 orang pemustaka yang telah memanfaatkan database jurnal internasional (Gambar 1). 


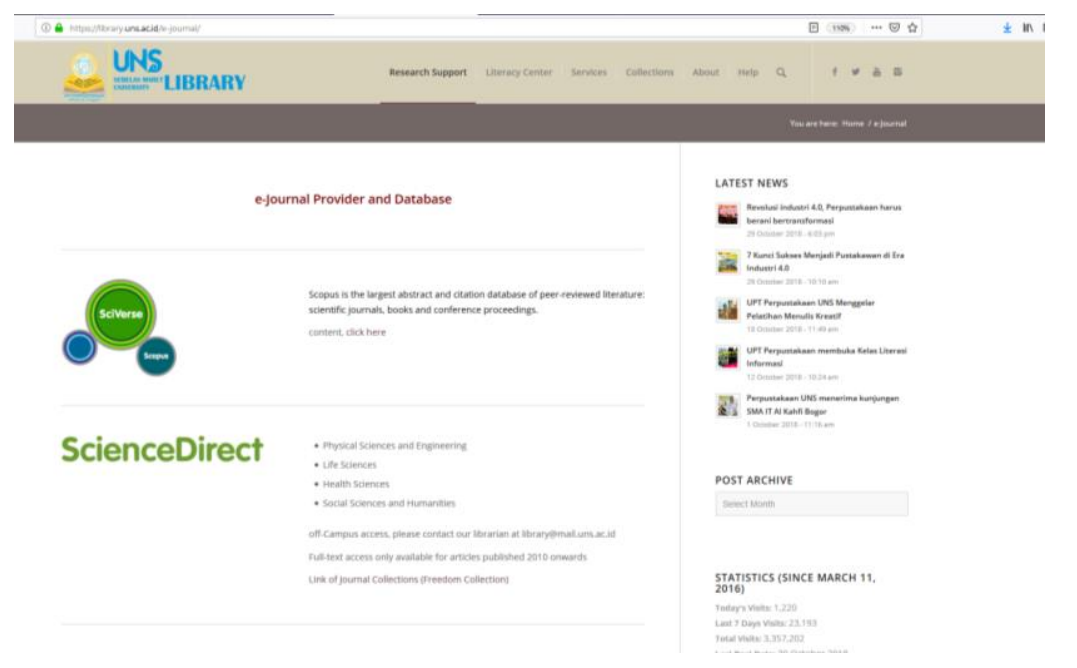

Gambar 1. Database Jurnal Internasional dan database Perpustakaan UNS

Adapun koleksi e-journal yang dapat diakses, antara lain sebagai berikut:

- Scopus. Bidang ilmu Scopus, mencakup ilmu sains, teknologi, kedokteran, ilmu sosial, seni, dan humaniora. Jurnal Scopus dapat diakses melalui laman http://www.scopus.com/.

- ScienceDirect. Bidang ilmu Science Direct, mencakup ilmu fisika dan teknik, ilmu kehidupan, ilmu kesehatan, ilmu sosial dan kemanusiaan. Jurnal ScienceDirect ini dapat diakses melalui lama http://www.sciencedirect.com/.

- E-Clinicalkey. ClinicalKey adalah "a medical search engine and database tool owned by medical and scientific publishing company Elsevier that offers access to the medical library published by that company". E-Clinicalkey ini dapat diakses melalui laman www.clinicalkey.com.

- Emerald, mencakup berbagai bidang ilmu. Database ini dapat diakses melalui laman http://www.emeraldinsight.com/. Koleksi di database ini berjumlah sekitar 292 judul, dengan keterangan perpetual access.

- China National Knowledge Infrastructure (CNKI). Database ini mencakup 90\% sumber-sumber pengetahuan China, yang mencakup jurnal, disertasi, koran, buku tahunan, buku kerja, ensiklopedia, paten, standar, dan dokumen peraturan hukum. Database ini dapat diakses di laman http:/oversea.cnki.net/kns55/. Jumlah koleksi di database ini sekitar 8.161 judul (per-Desember 2019).

- EBSCO. Bidang ilmu EBSCO mencakup ilmu perpustakaan, ilmu pengetahuan \& teknologi informasi, pertanian, komputer \& ilmu terapan, ilmu teknik. Database EBSCO dapat diakses melalui laman http://search.ebscohost.com/.

- ProQuest. Bidang ilmu ProQuest mencakup ilmu seni \& humaniora, dan ilmu biologi. Database ProQuest dapat diakses melalui laman http://search.proquest.com/. Jumlah koleksi di database ini sekitar 1.668 judul (dalam proses melanggan kembali).

- Cambridge, mencakup berbagai bidang ilmu. Database ini dapat diakses melalui laman http://journals.cambridge.org/, dengan jumlah koleksi sekitar 336 judul.

- The International Nuclear Information System (INIS). INIS menjadi salah satu koleksi terbesar bidang iptek tentang nuklir. Database ini juga menawarkan akses online ke 
repositori non-konvensional. Database INIS dapat diakses melalui laman https://www.iaea.org/resources/databases/inis.

- Perpustakaan Nasional RI, mencakup berbagai bidang ilmu, dan databasenya dapat diakses di laman http://new-eresources.pnri.go.id/.

\section{2) Perpustakaan Digital}

Perpustakaan digital merupakan institutional repository yang dikembangkan sendiri oleh pengembang perangkat lunak UNS. Database perpustakaan digital ini dapat diakses di laman https://digilib.uns.ac.id (Gambar 2).

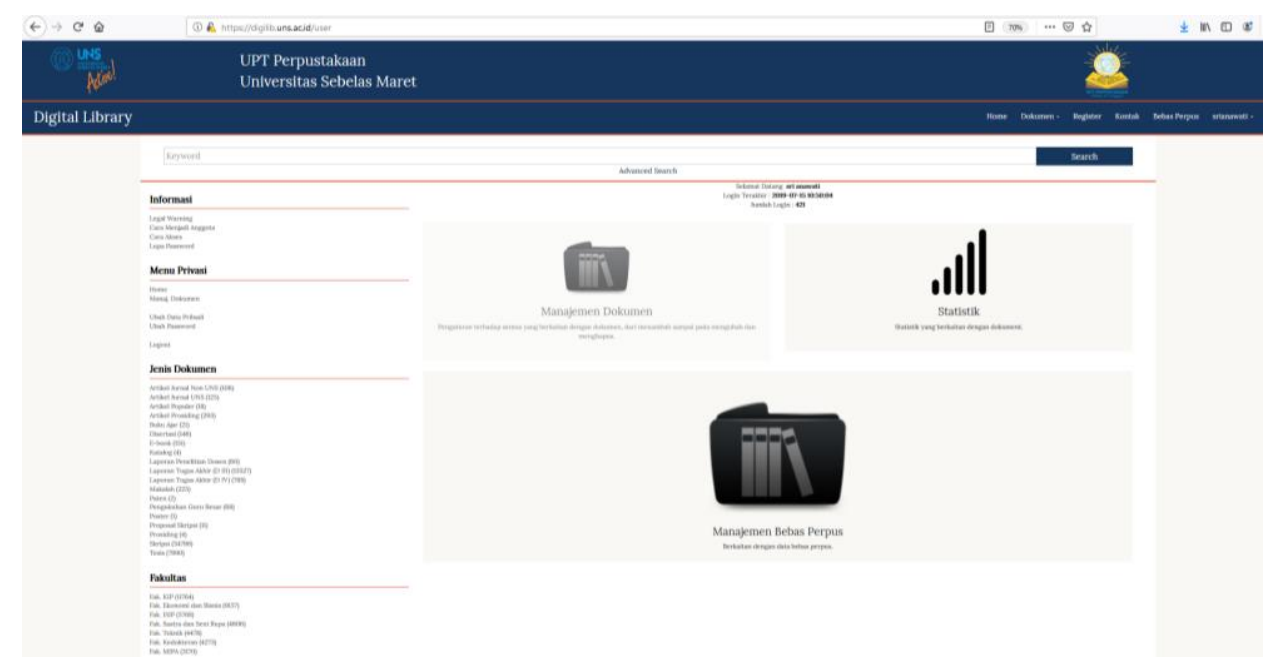

Gambar 2. Databae Perpustakaan Digital Perpustakaan UNS

Konten database ini merupakan hasil karya ilmiah sivitas akademika UNS. Pengguna dapat dapat melihat dan membaca konten fultext-nya jika sudah terdaftar sebagai anggota Perpustakaan UNS. Jenis dokumen dan jumlah data artikel per-Juli 2019, yaitu: Artikel Jurnal Non-UNS (106 judul), Artikel Jurnal UNS (125 judul), Artikel Populer (18 judul), Artikel Prosiding (293 judul), Buku Ajar (21 judul), Disertasi (146 judul), E-book (151 judul), Katalog (4 judul), Laporan Penelitian Dosen (60 judul), Laporan Tugas Akhir/D III (13527 judul), Laporan Tugas Akhir/D IV (788 judul), Makalah (225 judul), Paten (2 judul), Pengukuhan Guru Besar (68 judul), Poster (1 judul), Proposal Skripsi (11 judul), Prosiding (4 judul), Skripsi (34796 judul), dan Tesis (7990 judul).

\section{3) Repositori Lembaga}

Repositori lembaga UNS menggunakan E-prints. E-prints tidak dikelola oleh Perpustakaan UNS tetapi oleh Bagian Data dan Informasi UNS. Database repositori UNS dapat diakses di laman http://eprints.uns.ac.id/ (Gambar 3). 


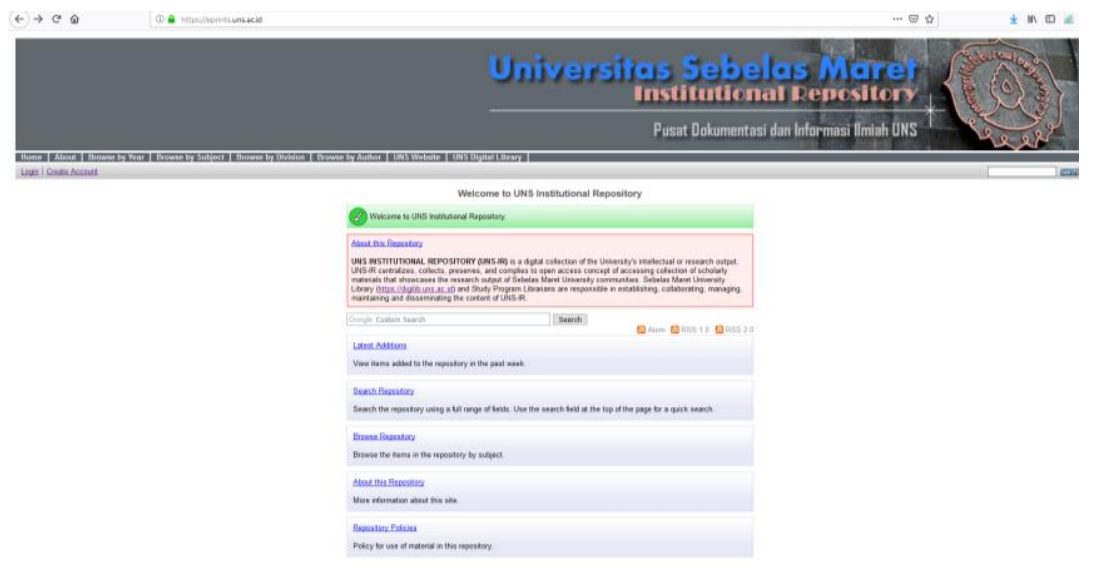

Gambar 3. Repositori Lembaga Perpustakaan UNS

\section{4) Sumber Literatur Lain}

Sumber literatur ini berupa jurnal-jurnal yang dihasilkan dan diterbitkan oleh sivitas akademika UNS dan diunggah menggunakan template Open Journal Systems (OJS), yaitu http://jurnal.uns.ac.id/.

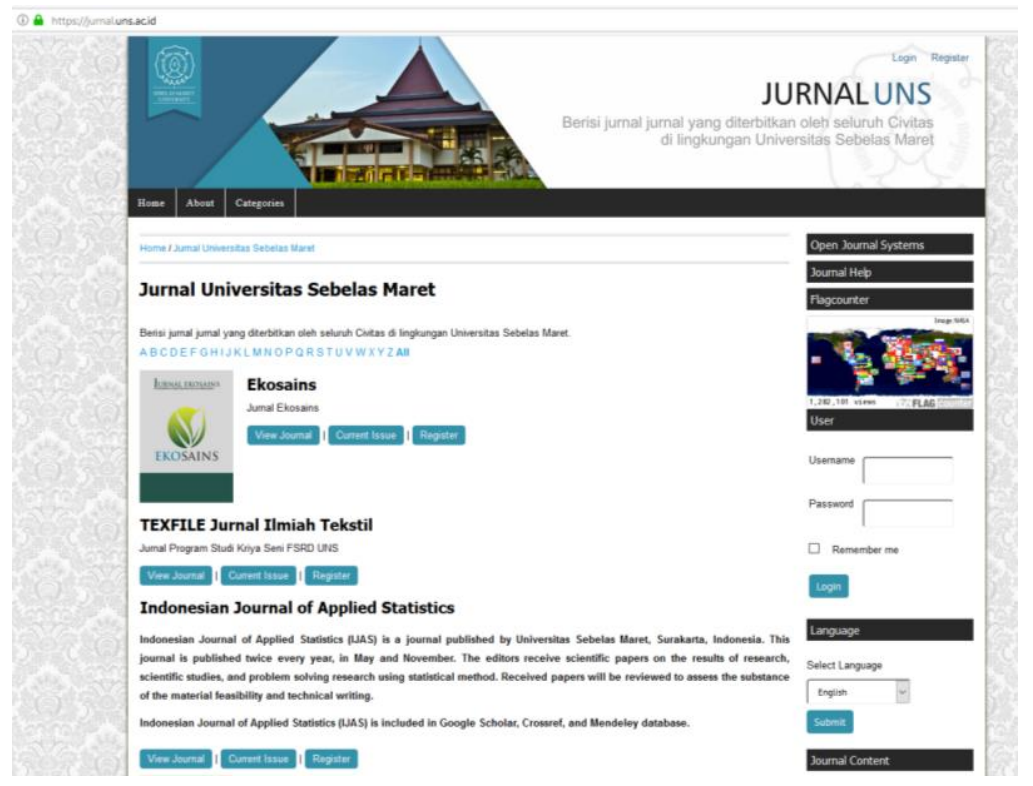

Gambar 4: Jurnal Universitas Sebelas Maret UPT Perpustakaan UNS

Untuk jurnal ilmiah (tercetak) UPT Perpustakaan UNS memiliki koleksi untuk jurnal yang diterbitkan UNS per Januari 2019 tersedia kurang lebih 78 nama jurnal, sedangkan untuk jurnal ilmiah (tercetak) yang berisikan artikel mengenai ilmu pengetahuan berdasarkan hasil penelitian yang diterbitkan oleh lembaga-lembaga ilmiah, perguruan tinggi, dan organisasi profesi. Saat ini UPT Perpustakaan UNS mengoleksi jurnal cetak yang terakreditasi Dikti terdapat 16 subyek sebanyak 98 judul dengan berbagai subyek, antara lain: Agama (6), Bahasa (8), Ekonomi, Bisnis (12), Hukum (8), Kedokteran (22), MIPA (2), Pendidikan (3), Pertanian (10), Kehutanan (1), Peternakan (2), Sosial, Politik, Komunikasi (10), Teknik Industri (6), Teknik Industri (3), Sain dan Teknologi (3), Ilmu 
Tanah (1), dan Seni (1). Jurnal ilmiah cetak tersedia di koleksi terbitan berseri berada di gedung lama lantai satu timur.

\subsection{Literasi Informasi}

Ada beberapa program literasi informasi di Perpustakaan UNS, diantaranya: (1) Pendidikan pemakai perpustakaan setiap tahun kepada mahasiswa baru. Kegiatan ini dilakukan pada saat osmaru waktu yang diberikan sekitar 15 menit. Pendidikan pemakai diperlukan untuk persiapan 'studi mandiri' mahasiswa-mereka diharapkan mampu memahami pemanfaatan fasilitas dan layanan informasi perpustakaan secara efektif dan efisien. (2) kolaborasi pustakawan dengan dosen, pimpinan fakultas, dan pemustaka dalam pemanfaatan informasi jurnal elektronik. (3) person by person atau kelompok mahasiswa yang mengajukan perrmohonan bantuan kepada pustakawan dalam penelusuran dan pemanfaatan jurnal internasional. Terkait hal tersebut, Perpustakaan UNS membuat pelatihan literasi informasi secara berkala yang dilakukan untuk mahasiswa dari berbagai fakultas dengan mengisi data diri undangan kegiatan (akses di https://library.uns.ac.id/). (4) Pelatihan literasi informasi secara periodik. Kegiatan biasanya diselenggarakan pada Bulan Februari Maret 2018. Materi kegiatan ini, mencakup: (a) how to access e-resources (e-journal, ebook, digital library, etc), yang dibagi menjadi dua sesi-sebagai contoh hari Selasa pada Minggu pertama pukul 09.00 - 10.00 WIB dan Selasa pada Minggu kedua pukul 09.00 11.00 WIB; (b) what is Turnitin and how does turnitin works, yang dibagi menjadi dua sesi-sebagai contoh hari Selasa pada Minggu ketiga jam 09.00 - 10.30 WIB dan Selasa pada Minggu keempat pukul 09.00 - $10.30 \mathrm{WIB}$; dan c) how to submit to an international journal (find the right journal, how to submit), yag dibagi menjadi dua sesi - sebagai contoh hari Rabu pada Minggu pertama pukul 09.00 - 11.00 WIB dan Rabu pada Minggu kedua pukul 09.00 - 11.00 WIB. Pemustaka atau mahasiswa yang mengikuti pelatihan literasi dapat langsung mendaftar sesuai jadwal yang diinginkan. Dalam pendidikan pemakai dan pelatihan literasi di atas, ada kegiatan komunikasi ilmiah dalam proses kegiatan tersebut. Dalam hal ini, pemustaka (mahasiswa dan/atau dosen) yang sedang atau telah selesai menyelesaikan tugas akhir (skripsi, tesis dan disertasi) dapat menulis kembali dalam bentuk artikel jurnal ilmiah.

\section{KESIMPULAN}

Perpustakaan UNS memiliki fungsi sebagai pengelolaan, penyimpanan, temu kembali informasi dan pelestarian mempunyai peran penting dalam komunikasi ilmiah. Perpustakaan UNS telah berperan dalam kegiatan komunikasi ilmiah, seperti penyediaan konten ejournal, perpustakaan digital, repositori lembaga dan sumber literatur lain, serta kegiatan literasi informasi. 


\section{DAFTAR PUSTAKA}

Lacy, W.B. \& Busch, L. 1983. Informal Scientific Communication in the Agricultural-Science. Information Processing Management. 19 (4), 193 - 202.

Lasa, H. S. 1998. Kamus Kepustakawan Indonesia. Yogyakarta: Pustaka Book Publisher.

Prahastuti, Sarwintyas. 2006. Pemanfaatan Jurnal Ilmiah Elektronik sebagai Sarana Komunikasi Ilmiah di Kedeputian Bidang Ilmu Pengetahuan Hayati - LIPI. Depok: Universitas Indonesia.

Priyanto, Ida Fajar. 2016. Kebutuhan dan Perilaku Pencarian Informasi, Komunikasi Ilmiah, Open Access, dan Perkembangannya. Makalah Perkuliahan MK Isu-Isu Kontemporer Informasi MIP UGM, 22 September.

Romanus, Beni. 2002. Scientific Communication Among Population Scientist in Indonesia. Paper presente at the IUSP Regional Conference on Southeast Asia's Population in a Changing Asian Context held at Siam City Hotel, Bangkok, Thailand, 10 - 13 Juni.

Romanus, Beni. 2002. Scientific Communication Among Population Scientist in Indonesia. Paper Presented at The IUSP Regional Conference on Southeast Asia's Population, in a Changing Asian Context Held an Siam City Hotel, Bangkok - Thailand, 10-13 June.

Sulistyo-Basuki. 1993. Pengantar Ilmu Perpustakaan. Jakarta: Gramedia Pustaka Utama.

Sulistyo-Basuki. 2014. Komunikasi Ilmiah dan Manfaatnya bagi Tenaga Pengajar dan Mahasiswa. Makalah Seminar Sehari Perpustakaan, Universitas Katolik Soegijapranata, Semarang, 24 Maret.

Sutarno. 2006. Perpustakaan dan Masyarakat. Jakarta: Sagung Seto.

Suyono, Riska Amaliah, Dewi Ariani, \& Ariva Luciandika. 2015. Cerdas Menulis Karya Ilmiah. Malang: Gunung Samudera.

Syihabuddin, Qalyubi, 2003. Dasar-Dasar Ilmu Perpustakaan dan Informasi. Yogyakarta: Fakultas Adab UIN Sunan Kalijaga.

Undang - Undang RI Nomor 20 Tahun 2003 tentang Sistem Pendidikan Nasional. Jakarta.

Undang - Undang RI Nomor 43 Tahun 2007 tentang Perpustakaan. Jakarta. 